\title{
Decade of Inclusive Education in Ghana: perspectives of educators
}

\author{
Maxwell Peprah Opoku \\ University of Tasmania \\ Joseph Agbenyega \\ Monash University \\ J-F \\ University of Tasmania \\ Wisdom Kwadwo Mprah \\ Kwame Nkrumah University of Science and Technology \\ Judith Mckenzie \\ University of Cape Town \\ Eric Badu \\ Kwame Nkrumah University of Science and Technology
}

\begin{abstract}
Inclusive education systems reflect growing awareness of the imperatives of $21^{\text {st }}$ century societies to make quality education available to all students. The development of inclusive education in Ghana has been recognized as the process for orchestrating educational quality and equity for students with disabilities. This article contributes to the area of inclusive education from Ghanaian educators on its progress and achievements. The data in this paper emerged from a case study involving educators from two regions in Ghana. Findings show an uncoordinated attempt to pilot inclusive education across the country because of different agencies funding the project. The authors argue that there is the need for a holistic review of the program to ground the policy within the education system of Ghana.
\end{abstract}

Keywords: Ghana, inclusive education, piloting, human rights, special educators

In 1990, the United Nations Conference on Inclusive Education in Thailand brought together a global voice to advocate for the education of students with disabilities in schools located in their communities (Anthony, 2011; United Nations Educational, Scientific and Cultural Organization [UNESCO], 1994). Human rights firmly contend that any and all segregation of school students in terms of their ability (i.e., physical, cognitive and vision) is morally inappropriate and discriminatory (Wang, 2009). Thus, the Education for All [EFA] initiatives are aimed at encouraging the participation of all 
students, irrespective of abilities, race, and gender (United Nations Students' Fund [UNICEF], 2012). Inclusive education is expected to benefit all students, regardless of their race, ability and gender (Agbenyega, 2003; Ashman, 2015; UNESCO, 1994). However, the United Nations (UN) found, discrimination to be a single underlying factor leading to the exclusion of students with disabilities from mainstream schooling (Lee, 2013; UNICEF, 2012). In addition, a recent joint report by the UNESCO, and UNICEF (2015) has found, that the global efforts toward achieving 'education for all' is yet to materialise due to discrimination which directly limits student's' access to education, and this is especially true in Africa.

Despite much progress, there are still over 58 million primary aged school students who are out of school, particularly in the African countries (The Africa-America Institute, 2015). More specifically, a significant number of these students are claimed to be students with disabilities (World Health Organization [WHO], 2011). This recognition has once again renewed calls for inclusive education in order to make education accessible to all students irrespective of one's disabilities (UNICEF, 2007). Consequently, the ratification of the United Nations Convention on the Rights of Persons with Disability [UNCRPD] gave meaning to the adoption of inclusive education by all the signatory states (United Nations, 2007). Ghana as a signatory state has since taken steps to safeguard the right to education for all students regardless of their abilities. Evidently, inclusive education has been piloted in Ghana since 2003 - 2004 academic year (Anthony, 2011; Gregorius, 2016; Opoku, Badu, Amponteng, \& Agyei-Okyere, 2015). Thus, after ten years it is important to evaluate the efficacy of these steps regarding its benefits, outcomes and the journey travelled in Ghana.

An operational definition for inclusive education within a Ghanaian context is important to provide insights into how the program has been implemented. However, in many ways, inclusive education in terms of its scope and policy have been shrouded in controversy due to the way it has been conceptualized; which inadvertently conflated how inclusive came to be implemented (Ainscow, Booth, \& Dyson, 2006; Clough \& Corbert, 2000; Kauffman, 1999; Forlin, 2012; Slee, 2013). One view argues that, inclusive education should merely focus on adaptation of the regular classroom to accommodate students with disabilities (Sharma, Forlin, Marella, \& Jitoko, 2016). While others emphasised a broader philosophical vision of extending it to create a culture of welcoming minority groups such as refugees, students in rural communities, orphans and others (Ainscow et al., 2006; Ashman, 2015; UNICEF, 2011). Irrespective of a particular focus, what needs to be evident in Ghana is the notion that these interpretations translate to assisting and aiding students with disabilities in their academic endeavours. Thus, this study will closely examine the extent to which practices in regular classrooms with regards to human development, curriculum adaption and others have enabled students with disabilities to actively participate in education (Sharma et al., 2016).

Teachers are at the heart of implementing inclusive education, and they should be suppored and trained to adopt different teaching strategies to support diverse students within in a classroom context (Ashman, 2015). Since the implementation of inclusive education in Ghana, it has been reported that there many challenges and barriers affect how it has been interpreted and operationalised at all levels of schooling (Agbenyega, 2007; Mprah, Dwomoh, Opoku, Owusu, \& Ampratwum, 2016; Obeng, 2007). For example, it was identified that teachers lacked skills to fully understand inclusive education within a classroom setting, as they reported a sense of unpreparedness in their ability to effectively teach students with disabilities (Agbenyega, 2007; Anthony, 
2011; Gregorius, 2016; Kuyini, Yeboah, Das, Alhassan, \& Mangope, 2016; Ocloo \& Subbeya, 2008; Mprah et al., 2016; Opoku et al., 2015, 2016). Other studies by Kuyini \& Desai (2007), Mamah, Deku, Darling \& Avoke, (2011), Mangope \& Obeng (2007) and Ocloo \& Subbeya (2008) also found lack of adequate training of teachers as a core barrier to teaching students with disabilities. So the question to investigate would be to capture the gravity of the problem in Ghana.

More broadly, studies in other countries have found that implementation of inclusive education has been encountering similar challenges (Ainscow, 2005; Forlin, 2006; Forlin, Keen, \& Barrett, 2008; Kalyanpur, 2014; Sharma, Simi, \& Forlin, 2015). For instance, in Portugal, a study by Campos, Ferreira, \& Block (2014) found that majority of educators reported lack of resources as one of the main barriers in supporting students with disabilities. In Cameroon, a study by Arrah \& Swain (2014) reported that teachers faced difficulties in terms of insufficient resources, lack of training, stress and being anxious, in supporting and teaching students with disabilities. Perhaps government agencies or education funding bodies are not adequately resourcing and/or funding schools. But to what extent resources are a barrier to implementing inclusive education in Ghana is not clear and this needs to be captured.

The above mentioned studies highlight an important complexity between operations, resourcing and training in inclusive education. Irrespective of these complexities, it is claimed that the challenges outweigh the benefits of inclusive education in terms of the overall benefit to the students and the wider community (Mitiku, Alemu, \& Mengsitu, 2014). In terms of teacher training, the problem could be two fold. One, it is likely that pre-service teachers are not fully appreciating the seriousness in understanding what inclusive education actually looks like within a school setting at the various levels (i.e., curriculum, classroom setting, and pedagogy). Two, perhaps the teacher training is not adequately equipping pre-service teachers with the needed skills (Mamah et al., 2011). It is unclear to what extent universities in Ghana have incorporated inclusive education into their core teacher-training program, and this must also be reviewed and evaluated.

\section{The context of the study}

However, this study aims to capture what inclusive education looks like in Ghana and the progress made in the last ten-year of piloting inclusive education programs in Ghana. Such a study is important as it will account for, capture what inclusive education looks like in Ghana since its implementation, and document the views of stakeholders on benefits, challenges and barriers. It is essential to point out that Ghana failed to introduce the policy in all public schools in 2015 which was a target set for all schools to accept students with disabilities (Opoku et al., 2015). So looking at inclusive education from the top-down, that is, from systems level to everyday operations, the voices of educators and implementers are likely to give a clear insight what inclusive education looks like in Ghana.

\section{Methods}

\section{Study participants and procedures}

A case study method was used to capture inclusive education through the voices of education in a Ghanaian context. The case study method is relevant to this inquiry 
because it aims to generate experiential knowledge from contextually bound problem through the collection of data from individuals' experiences, as it relates to their understanding of intrinsic aspects embedded in the case (Flyvbjerg, 2011; Tobin, 2010). Sixty participants (i.e., $58 \%$ males and $42 \%$ were females; and $37 \%$ were between 31 40 years of age) took part in the study. The study included participants who were purposively selected from the Special Education Division (SPED) of the Ghana Education Service in Accra and special educators from both Ashanti and Brong Ahafo regions. The criteria for selection was based on individuals' knowledge and their role in the implementation of the inclusive pilot program. The study was cleared by the Kwame Nkrumah University of Science and Technology's Ethics Research Review Board (Ref. CHRPE/AP/103/14). An invitation letter was sent to the Director of SPED at the head office in Accra, which was then circulated to other departments at SPED. After the approval, meetings were arranged with the department heads and all parties agreed on a date for the interviews. Information about the study via a letter from SPED was also sent to all district special education coordinators and school heads in districts piloting the program in both regions. Separate meetings were held with the headmasters, district special education coordinators, and resource teachers to explain the purpose of the study and to fix dates for interviews. Majority of participants interviewed were classroom teachers with less than 10\% recruited from SPED head office (see Table 1 below).

Table 1: Distribution of respondents

\begin{tabular}{lll}
\hline Categories & Frequency & Percentage (\%) \\
\hline Sex & 35 & 58 \\
Male & 25 & 42 \\
Female & & \\
Age & 14 & 23 \\
$21-30$ & 22 & 37 \\
$31-40$ & 15 & 25 \\
$41-50$ & 9 & 15 \\
$51-60$ & 39 & \\
Mean age & & 18 \\
Years of working experience & 11 & 22 \\
$1-5$ & 13 & 8 \\
$6-10$ & 5 & 17 \\
$11-15$ & 10 & 23 \\
$16-20$ & 14 & 12 \\
$21-25$ & 7 & \\
$26-30$ & 15 & 7 \\
Mean working experience & & 53 \\
Location of participants & 4 & 40 \\
Special Education Division (Accra) & 32 & \\
Participants from Ashanti region & 24 & 7 \\
Participants from Brong Ahafo & & 10 \\
Category of participants & 4 & 40 \\
SPED Headquarters & 6 & 27 \\
District special education coordinators & 24 & \\
Headmasters & 16 & \\
Classroom Teachers & & \\
Resource teachers & & \\
\hline
\end{tabular}




\section{Data collection}

The first author did both interviews and documentary reviews. The data collection began with reviewing documents on the number of schools piloting inclusion which was obtained at SPED headquarters in Accra. This enabled the first author to access information on the total number of schools piloting the program. Secondly, a structured in-depth interview guide was used to collect data from participants. Officials of SPED, head teachers, teachers, resource teachers and district special education coordinators (who are in charge of the education of students with disabilities in districts) were interviewed on the progress and challenges of the pilot program. Questions in the interview guide were open ended, with probes to prompt for further information.

\section{Data analysis}

Data analysis was informed by Braun \& Clarke (2006) notion of thematic analysis. The interviews were analysed thematically by following a four-stage process: data reduction (coding), identification of themes, organising themes and description of thematic networks. The first author read all the transcripts and highlighted salient issues that emerged from the transcripts. Codes were assigned to common issues identified by participants. Afterwards, themes were developed from the coded texts. The first author read the coded texts to identify the patterns of participants' responses. Following this, the themes were arranged together into coherent groups, and basic themes were condensed into organised themes, which were given common names. The final stage was the description of the thematic networks based on which the data were interpreted.

\section{Results}

\section{Coverage of the pilot program}

Documents available at SPED revealed that inclusive schools were classified into three namely, Government inclusive schools, United Nations Children's Fund [UNICEF] inclusive schools and United Nations Educational, Scientific and Cultural Organization [UNESCO] inclusive schools.

\section{Government inclusive school}

It was revealed that in 2003/4 academic year, the Government of Ghana through SPED and in partnership with Voluntary Service Overseas [VSO-UK] started the inclusive pilot project in 10 districts in three regions, that is, Central, Greater Accra and Eastern regions. In all, 60 schools were selected for the pilot program. Out of the 60 schools, 24 (40\%) were selected from four districts in the Greater Accra region, 20 (33\%) from three districts in the Central region and $16(27 \%)$ from four districts in Eastern region. Information about the Government inclusive schools and their location is presented in Table 2. 
Table 2: Distribution of inclusive schools in Government selected regions

\begin{tabular}{|c|c|c|c|c|}
\hline \multirow[t]{2}{*}{ Regions } & \multirow[t]{2}{*}{ Districts } & \multirow{2}{*}{$\begin{array}{l}\text { Number } \\
\text { of } \\
\text { Schools }\end{array}$} & \multicolumn{2}{|c|}{ Educational level } \\
\hline & & & $\begin{array}{l}\text { Primary } \\
\text { school }\end{array}$ & $\begin{array}{c}\text { Junior secondary } \\
\text { school }\end{array}$ \\
\hline Greater & Accra Metro & 7 & 6 & 1 \\
\hline \multirow[t]{3}{*}{ Accra } & Ga West & 5 & 5 & - \\
\hline & Dangbe East & 6 & 5 & 1 \\
\hline & Ga East & 6 & 6 & - \\
\hline \multirow{3}{*}{$\begin{array}{l}\text { Central } \\
\text { region }\end{array}$} & Cape Coast Mun. & 5 & 5 & \\
\hline & Ewutu/Effutu/Senya & 8 & 5 & - \\
\hline & Agona District & 7 & 7 & 3 \\
\hline \multirow{3}{*}{$\begin{array}{l}\text { Eastern } \\
\text { region }\end{array}$} & New Juabeng & 4 & 4 & - \\
\hline & Birim South & 5 & 5 & - \\
\hline & Yilo Krobo & 3 & 3 & - \\
\hline
\end{tabular}

\section{UNICEF inclusive schools}

Responses from officials at SPED as well as records available revealed that in 2010 UNICEF provided funding for the program to be extended to 1486 schools in 13 deprived districts in Central, Eastern, Northern, Upper East, Upper West and Volta regions. It should be noted that all basic schools in these districts were chosen to roll out the program. It is also worthy to note that both government and UNICEF programs did not include Ashanti and Brong Ahafo regions. Table 3 summarises the United Nations Students Fund's inclusive program districts.

Table 3: List of United Nations Students' Fund inclusive districts

\begin{tabular}{ll}
\hline Region & Number of districts \\
\hline Central Region & 2 \\
Eastern Region & 2 \\
Northern Region & 3 \\
Upper East Region & 2 \\
Upper West Region & 3 \\
Volta Region & 1
\end{tabular}

UNESCO inclusive schools

UNESCO provided funds for the program to be extended to three districts Ashanti and three districts Brong Ahafo Regions in 2011. In the districts selected in the Ashanti region were Agona Sekyere South, Obuasi Municipal and Ejisu-Juaben Municipal while those in Brong Ahafo were Atebubu-Amangten, Nkoranza Municipal and Tano South. Documents revealed that ten schools were selected in each district to pilot the program. This means that every region was expected to have 30 schools piloting the program. 
However, it was revealed during discussions with participants that only 19 schools were practising the inclusive program in Ashanti region at the time of the study. In the Brong Ahafo region, only one school was practising inclusive education while the other two districts had no school practising inclusion. Table 4 summarises UNESCO inclusive program districts and schools practising the program.

Table 4: UNESCO inclusive districts in Ashanti and Brong Ahafo regions

\begin{tabular}{llll}
\hline Region & District & & Number of schools \\
\hline Ashanti & Obuasi Municipality & 8 & \\
& Ejisu Municipal & 5 & \\
& Agona Sekyere South & 6 & \\
& & \\
Brong Ahafo & Tano South & 1 \\
& Nkoranza Municipal & 0 \\
& Atebubu Amanteng & 0 \\
\hline
\end{tabular}

Interestingly, officials at SPED could not provide information on the number of students in the schools across the country. However, officials at the districts in Ashanti and Brong Ahafo regions were able to provide information on the number of students with disabilities in schools in their respective districts. Table 5 below provides information on the number of students with disabilities in school in the selected districts.

Table 5: Number of students in schools in the districts

\begin{tabular}{llllllll}
\hline District & \multicolumn{3}{c}{ No. of students } & \multicolumn{5}{c}{ Type of Disability } \\
& Boys & Girls & Total & VI & HI & ID & OTHER \\
\hline Bechem & 21 & 15 & 36 & 33 & - & - & 3 \\
Atebubu & - & - & - & - & - & - & - \\
Nkoranza & - & - & - & - & - & - & - \\
Obuasi Municipal & 48 & 37 & 85 & 25 & 18 & 22 & 20 \\
Ejisu Municipal & 29 & 23 & 52 & 12 & 10 & 14 & 16 \\
Agona & 47 & 35 & 82 & 33 & 13 & 21 & 15
\end{tabular}

VI=Visually impaired; HI=Hearing impaired; ID=Intellectual disability

Progress made in Ashanti and Brong Ahafo regions 
Participants shared their views on the progress made so far about the pilot. While officials at SPED believed that the program had not gone well as expected, educators in the districts were of the view that the program was of course, although they acknowledged that there were challenges affecting the implementation of the program. Two officials of SPED comment as follows;

We have failed as a country with this piloting. We have to restart all over again since things did not go as planned. We are now in the process of selecting another 14 schools to begin again. As a division, we realized we will not be able to roll out the program nationwide, so there is the need for us to rethink and start again (SPED Official 1).

The program began very well, but we messed up along the line. We have learnt our lessons, and l'm sure things will be done differently in our next line of action. We have analysed it, and I think we will not repeat these mistakes again. We tried our best to broaden the piloting, but we encountered several challenges which didn't give us the best outcome expected, so we have to do things differently going forward (SPED Official 2).

Comments by special educators at the districts were, however, more optimistic than the gloomy picture painted by the two SPED officials as in the following quotes.

We have tried our best as a team to cover some schools. Our staff strength determines the number of schools we could cover. Since there are five resource teachers posted in the district, we could only cover five schools. On the whole, we have done something, which is an even achievement (District official 1).

I will say that it has not been easy, but l'm doing my best to make sure that the program succeeds in this district. There is no support coming to help implement the program, but I use the little resources I mobilise to fund our programs. We have not been able to cover the required schools, but l'm happy with what we have done so far (District official 2).

\section{Challenges identified}

Several challenges hindering the smooth implementation of the inclusive education were identified. These are inadequate funding, inadequate teaching resources and materials, inaccessible school environment and insufficient well-trained teachers in general schools.

\section{Limited funding}

There was a consensus among all the participants that schools piloting the programlacked funds to implement the program. According to an official of SPED, the central government provided funds for only special schools. Inclusive schools were to be considered in schools benefiting from government subvention. A district special education coordinator supported this claim and said that: 
Since I came here, I have not received any fund or seen a record of any fund brought to this office by the government. Anytime I go to the schools and see a child with a disability, I invite the parent to come around for discussions and counselling. I have a program for them, but all depends on money. Most of them had not registered for the National Health Insurance Scheme [NHIS], and I corroborated with the district assembly to get some for them (District Coordinator 1).

According to some of the participants, even the capitation grants (government subventions to all schools to support administrative expenses) was not being released making it difficult for the smooth running of the schools. A Resource Teacher remarked:

The biggest problem has been financing. The capitation grant is woefully inadequate to support the regular administration and not to talk about catering for the students with disabilities. No money comes from anywhere. The in-service- training we organised for the teachers come from our own pockets. Apart from the Braille sheets, no other materials come from anywhere. No reading textbook for them (Resource Teacher 1).

Certainly, without funding, it will be difficult to successfully to implement inclusion since funds are needed to acquire the necessary resources to support teaching and learning of students with disabilities in general schools.

\section{Lack of teaching and learning materials}

With the availability of teaching and learning materials, such as assistive devices and adapted textbooks and curriculum, participants revealed that there were no materials supplied purposely for teaching students with disabilities. For example, one headmaster and district special education coordinator said that they had not been given any material for teaching students with disabilities. The headmaster summarised as follows:

We have never received any material for special need students. No resources such as E-chart, auto-scope for assessment. When you are working and given the necessary resources, you are motivated. We do not have any materials solely for students with disabilities. So how do we teach them? (Headmaster 1)

An official at SPED supported this claim and mentioned that the only thing they gave to the schools was resource teachers posted to the schools to support classroom teachers and students with disabilities. If the resources that are needed to enhance the success of the pilot program were lacking in the schools, the objective of the program could not be achieved.

\section{Inaccessible school environment}

Almost all participants agreed that the physical environment of the schools was inaccessible to students with disabilities. For example, a resource teacher said that the schools were built without taking into account the needs of students with disabilities and this would make it difficult for them to move freely but there was 
nothing they could do about it (Resource Teacher, 9). An official at SPED also acknowledged the presence of physical barriers in the schools and said:

We are aware of the nature of environments in schools. We have sent proposals to the ministry of education, local government and finance ministry to consider the needs of students with disabilities when they are considering building new school facilities (SPED Official, 4).

\section{Lack of skills of teachers}

Participants said that most of the teachers in inclusive schools lack the skills to teach students with disabilities. Officials at SPED confirmed this assertion and indicated that almost all teachers in general schools had little knowledge about special education making it difficult for them to respond to the needs of students with disabilities in their classrooms. A resource teacher also indicated some teachers complained that it was difficult for many them to communicate with deaf students because they were not trained to teach such students. It was however found that there were few resource teachers to support the regular classroom teachers. The resource teachers had been posted to the schools to support classroom teachers. Since there were few resource teachers, many of the classroom teachers were not receiving the needed support. Some teachers discussed the technique they used to teach students with disabilities in their respective classrooms as follows:

I mostly sit beside the person when it is time for reading for them to follows their lesson. At times, I describe for them to picture in their minds and those around too, I show it to them for them to have a feel of it. The big problem is that anytime you are teaching them, you have to go to where they are while teaching (Teacher 1).

Those with low vision, I try to bring them in front during class sections. Those with long sightedness, I place them at the back. I detect it when we are writing notes. They normally come closer to the board to read (Teacher 5).

One of the resource teachers said that "each school I go to has six to eight classrooms and I cannot be in all these classrooms at the same hour of my visit." Similarly, headmaster added that:

The resource teachers are supposed to be in every classroom, but they are not enough. We have seven classes where the visually impaired students are. However, we have only three resources teachers. There should have been one in every classroom assisting them but how can three teachers all be in seven classrooms? (Headmaster 2)

\section{Discussion}

In terms of journey travelled and progress made since the piloting of inclusive education in Ghana, this study confirms that the implementation has been slow due to poor coordination as well as an improper selection of schools for the piloting program. The main finding within the Ghanaian context is that the pilot program has not added a 
tangible advancement in inclusive education, but it appears that it might have indirectly increased the awareness of inclusive education within the education sector. This in itself may not be a sufficient outcome after ten years. The findings of the study do also indicate that there was wide coverage of the piloting program, which might have affected the quality of implementation. More precisely the study found scarce learning materials, unqualified teachers, inaccessible physical environment and improper teaching methods to be very evident in schools that have implemented inclusive education. However though, many schools seem to have done their best and made provisions to deliver education as best as they could to students with disabilities, there is little or no evidence to show the gains or benefits to students or even schools.

This study found that the distribution of schools were not an accurate representative sample of schools, as there were imbalances in the selection of schools. For instance, the study found that districts identified by the government to pilot the program were only concentrated in certain parts of the country (mainly the coastal areas), thus, alienating other regions. Interestingly, key regions such as Ashanti and Brong Ahafo regions were excluded in the first seven years of the program. UNESCO's 2011 extension of the pilot into six districts in these two regions and ten schools in each of the districts were believed to have been selected for the piloting. However, the findings showed that none of the regions had up to that number of schools. For example, in Ashanti region, the study found that 19 schools were piloting the program whiles only one school in Brong Ahafo region was found doing same. More specifically, the study found that a high number of schools were supposedly practising inclusion in Ashanti region but human resources, teacher support and learning materials were unavailable to facilitate inclusive education for students with disabilities. Elsewhere in Brong Ahafo region, there were neither resources nor personnel to support the implementation of the program. Perhaps, this is evidence of improper planning and poor coordination, and lack of overarching inclusive education policy (Ainscow, 2005; Forlin, 2006; Opoku et al., 2015).

Attempts to remove barriers for implementation inclusive education were not evident in this study; it seems that international organisations set out their own priorities areas to implement the program, which seems to have mixed consequences on the outcome of the program. As this study found that schools were not properly prepared for the implementing of inclusive education policy. According to Kalyanpur (2014), international organizations assisting developing countries to implement inclusive education lack understanding of local context, which contribute to its failure. It is not surprising that SPED admitted failure in the piloting as they were contemplating restarting afresh with 14 new schools.

The goal of enabling students with disabilities enjoy their right to education was not achieved fully, as the needs of students with disabilities were not catered by mainstream schools. While there are special schools are in Ghana, their enrollment numbers are small and it is very unlikely many students with disabilities be able to access these centers of learning (Anthony, 2011; Opoku, 2016). So if a student is unable to get into a special school, they are likely to either endure a long wait or miss out on these schools (Opoku, 2016). In the midst of unpreparedness of regular schools to accept students with disabilities, they suffer systematic violation of their right to education even though they are to be safeguarded by the law.

Students with disabilities need much care, and they require materials to make their education successful in environments especially those that were not initially established 
for them (Campos, Ferreira, \& Block, 2014; Kalyanpur, 2014; Sharma et al., 2016). But the study found lack funding for teaching and learning materials. It is important to note that lack of teaching and learning resources have been significant barrier impeding the practice of inclusive education (Arrah \& Swain, 2014; Mprah et al., 2016; Opoku et al., $2015,2016)$. So the concern still remains in Ghana of lack of appropriate teaching and learning materials, making it impossible for students with disabilities to enjoy their rights to education as safeguarded by various legislations in mainstream schools (Agbenyega, 2007; Anthony, 2001; Ocloo \& Subbey, 2008; Opoku et al., 2015).

This study also found teachers to lack the necessary skills to work with and support the needs of students with disabilities in their classrooms. This finding is consistent with studies by Arrah \& Swain (2014), Kuyini \& Desai (2007), Mamah et al., (2011), Mangope et al., (2013), Obeng (2007), and Ocloo \& Subbeya (2007). It is not surprising that the only way teachers could assist students was to change their sitting arrangements merely. Unfortunately, resource teachers who were trained to support classroom teachers were found to be few and unable to extend their services to many schools and teachers. It was found that only one resource teacher was attached to inclusive schools having six or more classrooms.

The study also found, the physical environment such as public places in schools to be unfriendly to empower the participation of students with disabilities (Gregorius, 2016; Ocloo \& Subbey, 2008; Opoku et al., 2015, 2016). It perhaps would have been better if schools received direct financial assistance from the government which they could use to address their contextual needs, this finding is in line with studies by Campos et al., (2014) and Mitiku et al., (2014). Without any financial support from the government, schools cannot do much to assist students with disabilities in terms of physical environment and infrastructure. Overall, the provision of resources, finance and human resources were found to be unavailable and highly inconsistent, and this according to Ainscow (2005) is a recipe for failure since teachers cannot do much if school environments do not support their teaching activities. Given these findings, one could conclude that there are lots of gaps and deficits in inclusive education within classrooms in Ghana.

\section{Policy implications and conclusion}

Implementation of inclusive education in Ghana, as a pilot program could have been effective, if a small number of schools were selected on baseline criteria all the way from rural to urban centres rather than including all schools in a particular district. A baseline data allows for critical comparisons and evaluations. This assertion was supported by Anyangwe (2004) who argues that piloting is effective when conducted with a small portion to make room for improvement as well as analysing cost benefit strategies. Although the decision of SPED to restart the program with few schools is a step in the right direction, they seem to have misused a lot of energy and resources on an exercise, which did not yield positive results. Perhaps SPED should redesign the piloting program as the current system appears not to be structured both at the systems levels and at the micro delivery level.

Importantly, there should be an effective coordination process between supervision agency such as the SPED and its regional and district officers for effective checks on the field. It is recommended further that the government should consider allocating funds to 
inclusive schools to enable them to acquire materials to teach students with disabilities. Moreover, the government of Ghana should show commitment to the program by providing schools with the necessary materials as well as providing infrastructure in schools to meet the needs of students with disabilities. Furthemore, there should be more programs in colleges of education and universities aimed at equipping pre-service teachers the skills needed to teach students with disabilities. With this, Ghana may be able to effectively implement inclusive education in a way that all disadvantaged students may participate equally.

\section{Limitation and recommendation for future research}

The study only considered the implementation of inclusive education at the primary school level in Ghana. Therefore, there is the need for future research to investigate the implementation of the program in secondary schools. Also, there is the need for future studies to consider getting the voices of students and parents in relation to their impressions about the implementation of inclusive education in Ghana. 


\section{Reference}

Agbenyega, J. (2007). Examining Teachers' Concerns and Attitudes to Inclusive Education in Ghana. International Journal of whole schooling, 3(1), 41-56.

Agbenyega, J. (2003). The power of labeling discourse in the construction of disability in Ghana. A paper presented at the Australian Association for Research in Education Conference. https://www.aare.edu.au/data/publications/2003/agb03245.pdf

Ainscow, M., Booth, T., \& Dyson, A. (2006). Improving schools, developing inclusion (Ed). London: Routledge.

Ainscow, M. (2005). Developing inclusive education systems: what are the levers for change? Journal of educational change, 6(2), 109-124.

Anthony, J., (2011). Conceptualising disability in Ghana: implications for EFA and inclusive education. International Journal of Inclusive Education, 15(10), 10731086.

Anyangwe, C., (2004). Introduction to human rights and international humanitarian law. UNZA Press for the School of Law, the University of Zambia.

Arrah, R., \& Swain, K. (2014). Teachers' Perceptions of Students with Special Education Needs in Cameroon Secondary Schools. International Journal of Special Education, 29(3), 101-110.

Ashman, A. (2015). Education for inclusion and diversity. (Ed). Melbourne, Vic. Pearson Education.

Braun, V. \& Clarke, V. (2006). Using thematic analysis in psychology. Qualitative Research in Psychology, 3(2), pp.77-101.

Campos, M.J., Ferreira, J.P., \& Block, M.E., (2014). Influence of an Awareness Program on Portuguese Middle and High School Students' Perceptions of Peers with Disabilities. Psychological Reports, 115(3), pp.897-912.

Clough, P., \& Corbett, J. (2000). Theories of inclusive education: a student's guide. London: Sage.

Flyvbjerg, B. (2011). Case study. In: N. K. Denzin and Y. S. Lincoln (eds.). The Sage Hand-book of Qualitative Research, 4th ed. Thousand Oaks, CA: Sage, pp. 301-316.

Forlin, C. (2012). Responding to the need for inclusive teacher education. Future directions for inclusive teacher education: An international perspective (Ed.). London: Routledge.

Forlin, C. (2006). Inclusive education in Australia ten years after Salamanca. European Journal of Psychology of Education, 21(3), 265-277.

Forlin, C., Keen, M., \& Barrett, E. (2008). The concerns of mainstream teachers: Coping with inclusivity in an Australian context. International Journal of Disability, Development and Education, 55(3), 251-264.

Gregorius, S. (2016). Exploring narratives of education: disabled young people's experiences of educational institutions in Ghana. Disability \& Society, 31(3), 322338.

Kalyanpur, M. (2014). Distortions and Dichotomies in Inclusive Education for Students with Disabilities in Cambodia in the Context of Globalisation and International Development. International Journal of Disability, Development and Education, 61(1), pp.80-94.

Kauffman, J. M. (1999). Commentary: Today's special education and its messages for tomorrow. The Journal of Special Education, 32(4), 244-254. 
Kuyini, A. B., Yeboah, K. A., Das, A. K., Alhassan, A. M., \& Mangope, B. (2016). Ghanaian teachers: competencies perceived as important for inclusive education. International Journal of Inclusive Education, 20 (10), 1009-1023.

Kuyini, A. B., \& Desai, I. (2007). Principals' and teachers' attitudes and knowledge of inclusive education as predictors of effective teaching practices in Ghana. Journal of Research in Special Educational Needs, 7(2), 104-113.

Lee, S. E. (2013). "Education as a Human Right in the 21st Century." Democracy and Education, 21(1), 1.

Mamah, V., Deku, P., Darling, S.M., \& Avoke, S.K. (2011). University Teachers' Perception of Inclusion of Visually Impaired in Ghanaian Universities. International Journal of Special Education, 26(1), pp.70-79.

Mitiku, W., Alemu, Y., \& Mengsitu, S. (2014). Challenges and Opportunities to Implement Inclusive Education. Asian Journal of Humanity, Art and Literature, 1(2), 118-135.

Mprah, K., Dwomoh, A., Opoku, M., Owusu, I., \& Ampratwum, J. (2016). Knowledge, Attitude and preparedness of teachers towards inclusive education in EjisuJuaben Municipality in Ashanti region of Ghana. Journal of Disability Management and Special Education, 6(2), 1-15.

Obeng, C. (2007). Teacher's Views on the Teaching of Students with Disabilities in Ghanaian Classrooms. International Journal of Special Education, 22(1), 96-102.

Ocloo, M. A., \& Subbey, M. (2008). Perception of basic education school teachers towards inclusive education in the Hohoe District of Ghana. International Journal of Inclusive Education, 12(5-6), 639-650.

Opoku, M. P. (2016). The state of special schools in Ghana: Perceptions of special educators in Ashanti and Brong Ahafo regions of Ghana. Turkish International Journal of Special Education and Guidance \& Counselling (TIJSEG) ISSN: 13007432, 5(1).

Opoku, M. P., Mprah, W. K., Owusu, I., Badu, E., \& Torgbenu, E. L. (2016). Challenges in accessing education for students with disabilities in Ashanti and Brong Ahafo regions of Ghana. Journal of Disability Studies, 1(2), 61-68.

Opoku, M. P., Badu, E., Amponteng, M., \& Agyei-Okyere, E. (2015). Inclusive Education at the crossroads in Ashanti and Brong Ahafo regions in Ghana: Target not achievable by 2015. Disability, CBR \& Inclusive Development, 26(1), 63-78.

Sandkull, O. (2005). Strengthening inclusive education by applying a rights-based approach to education programming. Paper presented at the ISEC Conference, Glasgow.

http://www.hiproweb.org/fileadmin/cdroms/Education/StrengtheninglE.pdf

Sharma, U., Forlin, C., Marella, M., \& Jitoko, F. (2017). Using indicators as a catalyst for inclusive education in the Pacific Islands. International Journal of Inclusive Education, 21(7), 730-746.

Sharma, U., Simi, J., \& Forlin, C. (2015). Preparedness of pre-service teachers for inclusive education in the Solomon Islands. Australian Journal of Teacher Education, 40(5), 103-116.

Slee, R. (2013). How do we make inclusive education happen when exclusion is a political predisposition? International Journal of Inclusive Education, 17(8), 895907.

The African-America Institute (2015). State of Education in Africa Report 2015. http://www.aaionline.org/wp-content/uploads/2015/09/AAl-SOE-report-2015final.pdf 
Tobin, R. (2010). Descriptive case study. A. J. Mills, G. Durepos and E. Wiebe. Encyclopedia of case study research. Thousand Oaks, CA, SAGE Publications Inc.

United Nations Educational, Scientific and Cultural Organisation. (1994). The Salamanca Statement and framework for action on speical needs education. http://www.unesco.org/education/pdf/SALAMA_E.PDF

United Nations Children's Fund. (2012). The right of the students with disabilities to education: A right based approach to inclusion education. http://www.unicef.org/ceecis/UNICEF Right Students Disabilities En Web.pdf

United Nations Children's Fund. (2011). The right of students with disabilities to education: A rights-based approach to inclusive education in the CEE/CIS region. Geneva: UNICEF Regional Office for Central and Eastern Europe and the Commonwealth of Independent States. http://www. unicef. org/ceecis/Background_NoteFINAL (1). pdf.

United Nations Children's Fund. (2007). Promoting the Rights of Students with Disabilities. http://www.un.org/esa/socdev/unyin/documents/students disability rights.pdf

United Nations Children's Fund. (2015). Fixing the Broken Promise of Education for All: Findings from the Global Initiative on Out-of-School Students. UNICEF. 3 United Nations Plaza, New York, NY 10017.

United Nations. (2007). Convention of the rights of persons with disability. http://www.un.org/disabilities/documents/convention/convoptprot-e.pdf

Wang, H. L. (2009). Should all students with special needs be included in mainstream education provision? A critical analysis. International Education Studies, 2(4), 155-157.

World Health Organization. (2011). World Disability Report. Geneva: WHO Press. http://www.who.int/disabilities/world_report/2011/report.pdf 


\section{Biographical Notes}

Maxwell Peprah Opoku started his early education at his place of birth before moving to Kumasi for his first degree in Political Science from Kwame Nkrumah University of Science and Technology. After serving a year as Teaching and Research Assistant, he developed an interest in disability which influenced his decision to enrol in Disability, Rehabilitation and Development for his second degree from this same University. He has a second masters in Governance and Regional Integration which is an African Union's flagship programme, at Pan African University, Cameroon. Currently, he is pursuing PhD at University of Tasmania as well as a tutor in Master of Teaching (Inclusive practices in educational settings).

Professor Joseph Seyram Agbenyega is senior lecturer and currently the Director of Graduate Research, Faculty of Education, Monash University. He is an expert of international repute in areas of early childhood and special education.

Dr J-F is senior lecturer at University of Tasmania with expertise in mental health, forensic psychiatry and education psychologist. He has research interest in special education and the inclusion of individuals with aggressive/difficult behaviours in education.

Dr Wisdom Kwadwo Mprah is a lecturer at Centre for Disability Rehabilitation Studies, Kwame Nkrumah University of Science and Technology with research interest in disability issues, gender, reproductive health and sexual violence.

Dr Judith McKenzie is a lecturer and Head of Disability Division at University of Cape Town. She an expert and a strong advocate for disability rights, especially people with intellectual disability. She is active in research focusing on inclusive education and family relations.

Eric Badu is a Ghanaian, with interest in Disability and Health research, human rights issues, and Capacity Building and Statistical data analysis. In 2013, he worked as Graduate Assistant, Centre for Disability and Rehabilitation Studies, where he led students to visit Community Base Rehabilitation Programmes for Persons with Disabilities. He had also worked as Teaching Assistant in the department of Modern Languages, Faculty of Social Sciences, KNUST from 2011-2012, where he organized tutorials for undergraduate students. 